\title{
IVNONES: AN APPROACH TO THEIR PERSONALITY AND GEOGRAPHY OF CULT
}

\begin{abstract}
Summary: The epigraphic expression of plural female divinities, represented sometimes in triads, is a feature of Romano-Celtic realms. This is the case of the Matres and Matronae, as well as the Fortunae, with epithets expressing the local identity of the divine personality - or of their cult group - in an increasingly globalized world such as the Roman Empire.

In this context, my aim is to focus on the Iunones. We have about 70 inscriptions dedicated to these deities, sometimes appearing with the epitet Augustae, others as Matronae, Montanae, Domesticae, Suleviae, associated with other deities such as IOM, Hercules, Genius Loci or the Augustorum Numina, or assimilated to the Gabiae. The sacred geography of the Iunones includes Italy (with a higher density in Venetia and Histria, but with manifestations in Transpadana, Umbria, Aemilia, Latium and Campania), but they are also testamented in diverse provinces of Celtic tradition, such as Germania Inferior, Noricum, Belgium, Aquitania, Lugdunensis or Narbonensis. The analysis of individual or collective dedicants, the activities commemorated in the altars, and the processes that make visible - at a regional or local level these goddesses in theonyms related to the Roman Iuno, are the aims of this paper.
\end{abstract}

Key words: Iunones, interpretatio, Matres, Matronae, Roman religion

The Landesmuseum Württemberg in Stuttgart houses the busts of the so-called "Three holy women". These three busts, from Anhausen (Schwäbisch Hall), are dated to 1506, and portray the Virgin Mary, Saint Barbara and Saint Dorothea (fig. 1). Without going into the meaning of these sculptures and the context they emerge from, which is clearly beyond the subject of this paper, I believe they somehow reflect the topic I am about to deal with: the interpretatio mechanisms in the world of holy female triads. The busts in the Museum of Stuttgart point, in my opinion, to the Christianization of ancient female 


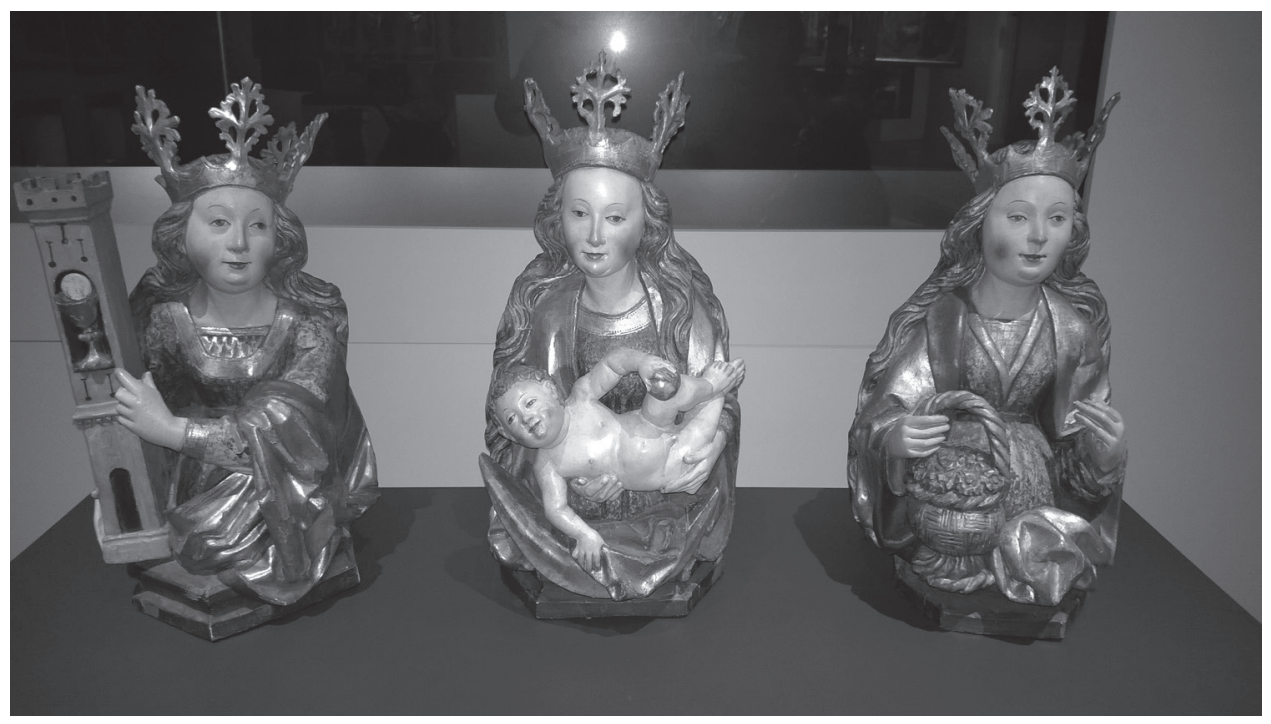

Fig. 1. "The Three Holy Women" (Anhausen, Schwäbisch Hall). Landesmuseum Württemberg in Stuttgart (photo: F. Marco Simón)

characters which are typical of Celtic areas, known to us mainly through the theonyms of Matres or Matronae. ${ }^{1}$

But these ancient female divine personalities can equally be mentioned as Iunones, the matter of our discussion here. And I think that this conference, Symposium Classicum Peregrinum, particularly befits the topic I am about to expound, since I am dealing with the adaptation of a classical goddess, the Roman Iuno, within a Celtic peregrine environment, through a process of multiplying a singular deity in triads, a process described by Pierre Lambrechts as "répetition d'intensité", ${ }^{2}$ which seems typical in Celtic realms as it can be seen also in iconography (for example, in the Gaulish god with the threefold head). In Gallia Narbonensis for example it is possible to document two different variants of expressing the same or similar deity related to waters and fertility: while in the more romanized context this deity is testamented through a masculine and singular theonym (Glanis, or Nemausus for example), in more "traditional" realms within the same location this divine personality is expressed through the pluralized feminine as we can read in the dedications to the matrebo glaneikabo and the matrebo namausikabo. ${ }^{3}$ The case of the Iunones seems to show a similar process of pluralisation of a singular Classical Roman deity known to us as Juno.

${ }^{1}$ In the same sense, PASCAL 1941, 372, observed that "the three Maries are a Christianized form of the Celtic-Germanic deities, the mothers (matres, matrones) to whose cult hundreds of Rhenish inscriptions testify", on the base of STUMPPFL 1936, 215ff.

${ }^{2}$ LAMBRECHTS 1942.

${ }^{3}$ JUFER-LUGINBÜHL 2001, 43 and 56, with references. 
A first observation is that the cult of these female deities of various appellatives (Matres, Matrae, Matronae, Iunones) is totally ignored in ancient literary sources: no reference is made, for instance, in Caesar's Gallic excursus, or in Tacitus' Germania, or in Seneca's - Epist. 110. 1-2, and Pliny's NH 2. 16 -, who report on less official aspects of the cult of Iuno as the female form of the Genius. This lack of reference to Iunones in ancient literary sources could be attributable to the private nature of the cult of these goddesses, as Landucci Gattinoni has pointed out. ${ }^{4}$ The purpose of this contribution is an approach to the geographical area where the cult of the Iunones took place, trying at the same time to explain the context of their epigraphical emergence and difussion.

\section{GEOGRAPHY OF THE IUNONES CULT}

So far, almost 70 inscriptions dedicated to Iunones have appeared, either on their own or associated with other deities. Over half of them, 38 epigraphs to be precise, have been found in Regio X (Venetia et Histria), where three central points concentrate the most significant elements of the geography of the cult: Brescia/Brixia (10 instances within the city and 18 in the surrounding territory: fig. 2 map), Verona (10 including the

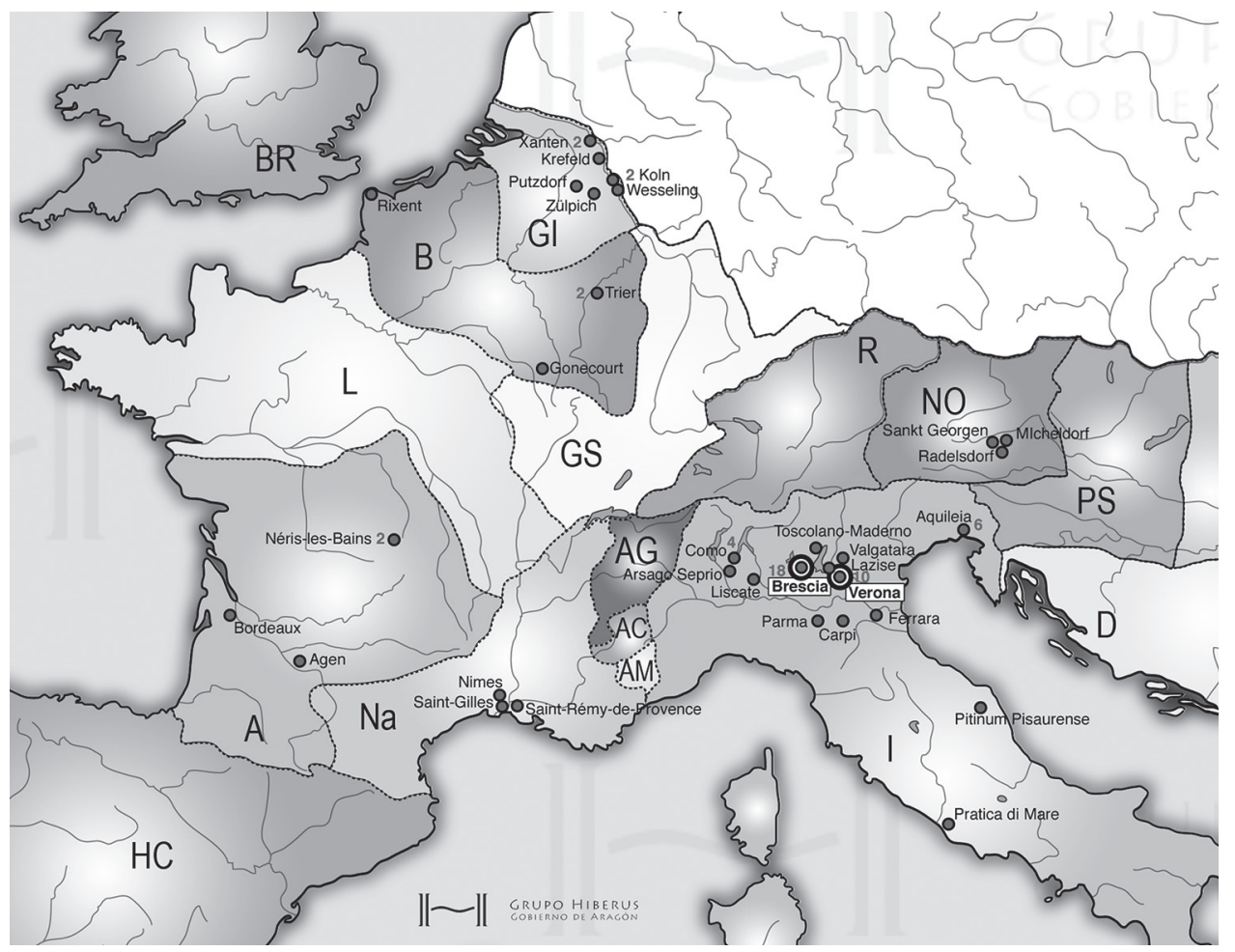

Fig. 2. Cultic geography of the Iunones (cartography: Peña Lanzarote)

${ }^{4}$ LANDUCCI GATTINONI 1986, 79. 
surrounding territory) and Aquileia (6 epigraphs). Out of the 6 inscriptions originate in neighbouring Transpadana, 4 of them appeared in Como and the surrounding territory, and the theonym has a weaker prevalence in Regio VII of Emilia (2 instances), in Umbria (1 instance) and in Latium (1 instance: Pratica di Mare/Lavinium, a case we shall review later).

The province of Germania Inferior is, after Venetia and Istria, the second zone in terms of number of epigraphs yielded, totalling 8, with Cologne and Xanten producing two epigraphs each. As regards the Gallias, a total of 10 inscriptions have been found, three of them in Gallia Narbonensis (in Nîmes/Nemausus, St. Gill and St. Rémy de Provence/Glanum), four in Aquitania (2 of them in Nerins-les-Bains/Aquae Neri) and four in Belgium (two of them in Trier/Augusta Treverorum). The cultic map is completed with the finds in Noricum, 3 in total, from Sankt Georgen/Tarnasicum, Micheldorf/Noreia and Radelsdorf (see Appendix).

Consequently, the geography of holy Iunones seems particularly visible in Veneto, with the key spots of Brescia, Verona and Aquileia, and to a lesser extent in Germania Inferior, with a presence in three Gallic provinces (but not in Gallia Lugdunensis, at least at the time of writing), and in the Noricum, plus scattered finds in Emilia, Umbria and Latium. No other documents of these deities have been attested to until now in provinces like Germania Superior, Raetia, the Alpine provinces, Britannia, Hispania, Dalmatia or Pannonia.

The Iunones are guardian deities of health and fertility and have been explained as a Romanized form of a local pre-Roman cult highly prevalent in the Cisalpine, in relation to the Matronae. ${ }^{5}$ The Brescia territory, where 18 of our shrines originate in and where Matronae are equally attested to, appears to be particularly relevant in this area and acts as a hinge between Regio X, where the cult to Iunones is prevalent, and Regio XI, where Matronae are predominant. ${ }^{6}$

Reference has been made to the propensity towards female cults in this zone, where deities such as Minerva, Venus or Isis-Fortuna prevail, and where male divinities are in the minority. In this context, the Iunones possibly represent cults of strong Cenomanian, that is Celtic, inspiration, also conceivably related to the dedications to the Fatae in the same zone ${ }^{7}$ which give 13 inscriptions in total. ${ }^{8}$ Likewise, an anonymous inscription from Vicenza is dedicated to the Dianae, ${ }^{9}$ whose plural expression could probably be due to - perhaps through Etruscan intervention - the fact that the Latin world already knew Diana's triple epiclesis derived from the Greek triad Artemis-Selene-Hecate (as is well known, a coin from Aricia depicts triple Diana). ${ }^{10}$

According to Claudio Zaccaria, besides Belenus, the great city deity worshiped in Aquileia with about 70 inscriptions, amongst the large amount of local deities doc-

\footnotetext{
${ }^{5}$ PASCAL 1964, 70, 116-123; LANDUCCI GATTINONI 1986; BASSI 2008, 52.

${ }^{6}$ GREGORI 2000, 273.

${ }^{7}$ BASSI 2008, 53-54.

${ }^{8}$ ZACCARIA 2001-2002, 147-148.

${ }^{9} A E 1959,260$. Two more inscriptions are dedicated to the Dianae in Saint-Dié-des-Vosges/Leuci
} (AE 1967, 321) and in Bure-la-Ville/Leuci (AE 1967, 427), in the Roman province of Belgica.

${ }^{10}$ LANDUCCI GATTINONI 1986, 51. 
umented in the Gallia Cisalpina only the Matres (Matronae, Iunones) seem more certainly to be Celtic. But they are themselves somehow probably the interpretatio of some unknown pre-Roman deities, and not only Celtic but also Raetic, Venetic, Etruscan or even "Istrian" substrata ought to be taken into consideration. ${ }^{11}$

As is well known, the Matres are worshipped in the transalpine world of Gallia, Germania, Britannia or Hispania, ${ }^{12}$ whereas the Matronae appear in epigraphs of the Cisalpine areas (some 59 altars are dedicated to the Matronae). Conversely, the Matres only appear on one occasion in Monte S. Martino, Brescia. ${ }^{13}$

Some scholars, such as Pascal or Landucci Gattinoni ${ }^{14}$ claim that the inscriptions dedicated to Matronae-Iunones could document in the Cisalpine the substantial identity of both deities. Nevertheless, of the total of 97 entries on Matronae and Iunones analysed by Landucci Gattinoni, only those from Macerata Feltria/Pitinum Pisaurense (No. 45), Verona (No. 10), Como (No. 39) and Arcisate (No. 40) are jointly dedicated to both plural designations. In other words: only 4 of the total 97 , which in my opinion makes the tout court identification of both theonyms rather problematic. As previously stated, Matronae are clearly predominant in the west, in Regio XI, whereas Iunones are more prevalent in Regio X (save for the territory of Brescia, bordering Regio XI).

\section{THE ORIGIN OF THE EPIGRAPHICAL EVIDENCE}

When interpreting the epigraphic emergence of the pluralized theonym Iunones, some scholars pointed out Roman Juno's value as the female correlation of the Genius, the protecting numen of individual households. ${ }^{15}$ The existence of an individual guardian Juno is demonstrated not only by the existence of shrines dedicated to Juno as a specific individual female character ${ }^{16}$ or by inscriptionas dedicated to Genius/Iuno as a pair, ${ }^{17}$ but also by literary sources. Tibullus relates explicitly woman with Iuno (3. 12. 1-20; 3. 6. 48: 3. 19. 15), indicating that on a woman's birthday offerings were made to her iuno (3. 12. 1-2: Natalis Iuno, sanctos cape turis acervos, quos tibi dat tenera docta puella manu), while Seneca (Epist. 110. 1-2) states that ita tamen hoc seponas volo, ut memineris maiores nostros, qui crediderunt Stoicos fuisse, singulis enim et genium et Iunonem dederunt. And Pliny (NH 2. 16) writes: quam ob rem maior caelitum populus

11 ZACCARIA 2001-2002, 129-130.

${ }^{12}$ Except for the inscriptions of the Germanic équites singulares found in Rome and dated to the first half of the second century (CIL VI 31140-31149; 31161; 31171; 31174-31175). Cf. HEICHELHEIM 1930; BAUCHHENS-NEUMANn 1987; GómEZ PANTOJA 1999.

13 ZACCARIA 2001-2002, 151.

14 PASCAL 1964, 187 or LANDUCCI GatTINONI 1986, 19.

15 IHM 1887 and 1894; LANDUCCI GATTINONI 1986, 20.

${ }^{16}$ CIL VI 2128: Iunoni Iuniae C. Silani f. / Torquatae sacerdoti Vestani annis LXIII caelesti patronage Actius 1; CIL VI 15502: Iunoni Claudiae Liviae 1. Melpomene; CIL VI 15675: Iunoni Cleopatrae L. ser. Alexander b.m.f.; CIL VI 25554: Iunoni Rubriae Victorinae.

${ }^{17}$ CIL XI 3076=ILS 116; cf. CIL V 5869, 5892 (=ILS 6730-6731), 6950, 7237; VIII 3695 (=ILS 3644); XIII 1735. 
etiam quam hominem intellegi potest cum singuliquoque ex semetipsis totidem deos faciant Iunones Geniosque adoptando sibi.

Wissowa saw in the pair genius/iuno the divinized essence of male and female creative power, and characterized the belief as a survival from the most primitive period of Italic religious thought. At an early period, however, the two concepts began to diverge, the genius remaining an individualistic concept while the mass of iunones produced a great goddess of women, Iuno. ${ }^{18}$ This theory remained dominant for many years in German scholarship, but has been dismissed by English and French scholars who have argued that the iuno feminae is a late development, ${ }^{19}$ indicating that there is little reason to think of the iuno and the genius as primitive survivals, but some reason to think that they developed in the two last centuries $\mathrm{BC}$, the iuno on the model of the genius, the earliest evidence for the iuno appearing in the Augustan period..$^{20}$

Whatmough $^{21}$ was the first to suggest that the use of iuno feminae derived from the description of the Celtic Matronae as iunones. Dumézil ${ }^{22}$ dismissed the notion of an archaic Latin concept or even a Frauengottheit and argued that Iuno was a goddess of Indo-European origin, a proper tripartite deity embodying warlike power, fecundity and sacred royalty.

$\mathrm{Ihm}^{23}$ proposed the hypothesis that, just as the Genius became with time the protector of human communities in a broad sense (cities, colonies or even provinces), Roman Juno's protecting role could well have been transferred onto social communities, bringing her closer to the features of Celtic-Germanic Matres-Matronae. Ihm's hypothesis could be supported by the inscription in Bergamo (CIL V 5112) dedicated to Iunoni Pagi Fortunensis, which could document the transformation of Iuno as a private numen into the guardian divinity of a small community.

Be that as it may, one of the aspects I would like to point out here in order to highlight the probable Celticity of Iunones is the scarcity of testimonies regarding Roman Iuno. ${ }^{24}$ The distinctive plurality in the expression of the female guardian divinity in Celtic and Germanic environments could also have favoured plurality as a feature attached to Roman Juno resulting from a typical interpretatio process. ${ }^{25}$ Iunones could therefore be the Romanized form of a pre-existing cult in Cisalpine, a hypothesis liable to be modified in the light of fresh epigraphic elements. ${ }^{26}$

I believe available documentation seems to endorse Ihm's hypothesis to explain the key of the cult of Iunones as documented in epigraphy. An altar in Trier is dedicated to the Iunones and to the Genius (CIL XIII 3642) association possibly repeated

18 WISSOWA 1912, 182.

${ }^{19}$ Rose 1948, 45ff.; BAYET 1957, 66; SCHILling 1979, 419; Rives 1992, 48-49.

${ }^{20}$ CIL XI 3076=ILS 116: Genio Augusti et Ti. Caesaris, iunoni Liviae, Mystes l/(ibertus), after AD 14 (RIVES 1992, 37 n. 15).

${ }^{21}$ WHATMOUGH 1937, 159ff.

22 DUMÉZIL 1954, 105-119; 1974, 303-310.

${ }^{23}$ IHM 1894.

${ }^{24}$ SARTORI 1995, 236.

${ }^{25}$ On the on interpretatio processes in general and their variants, see now the proceedings of the Osnabrück conference: CHIAI-HÄUSSLER-KUNST 2012.

${ }^{26}$ LANDUCCI GATTINONI 1986, 21. 
in the shrine of Carpi (Emilia), which I shall mention later (No. 43). I equally believe that a reference should be made to the Krefeld inscription (Germania Inferior), where the Numen Augusti and the Genius Loci are cited along with our goddesses by the dedicator, Silvinius Nocturnus (No. 65).

\section{EPITHETS AND ASSOCIATION WITH OTHER DEITIES}

Two of the testimonies from Transpadane are addressed to the Iunones Matronae as a result of a vision the dedicator had - of threefold name in Como (No. 39) -, while in the case of Arcisate the dedication is made by Valerius, son of Baro (No. 40). A similar association with the Matronae is attested to in another inscription from Pitinum Pisaurense, Umbria, dedicated by Cinnamis (No. 45), as well as on another gravestone from Verona where these Iunones are perhaps described as Augustae (No. 10).

The Domnae (Dominae) Iunones are attested to in an altar in Verona dedicated by Exspectata (No. 14), and 4 inscriptions in the zone of Aquileia are dedicated to deities called Dominae, which could possibly refer to the Iunones ${ }^{27}$ as they do not appear to be linked to any other theonym besides these.

An epigraph in Toscolano Maderno, also in Veneto, jointly invokes Hercules and the Iunones (No. 37), described as Dii Sancti by a couple of Roman citizens with a threefold name, to favour another person who must be their son, L. Valerius Cornelianus. This is a highly interesting altar in terms of the relationship between Juno and the Iunones, since in the ancient Roman religion Juno and Hercules appear as the main female and male numen, as a pair of dei coniugales. ${ }^{28}$

Iunones are accompanied by the Augustal epithet in an inscription from Calvisano, in the ciuitas of Brescia, made by Euelpistus (No. 30), as well as in two altars in Verona (Nos. 12-13) and one in Mezzane di Sotto (No. 29). The Augustal epithet describes also the Iunones in an inscription from the Narbonensis originating in St. Gilles, inside the ciuitas of Nimes (No. 48), while in neighbouring Aquitania an altar was found in Agen (No. 51) dedicated to the Iunones Augustales and registering the erection of a portico and a wall (maceria) by two dedicators, Capito and Julia.

The association of Iunones with Numina Augustorum ${ }^{29}$ and the Genius Loci documented in Krefeld-Gellep/Gelduba (No. 65), which may be dated to between the late second century and the middle third century (fig. 3), is not attested to in any other place, while the association of the Iunones with the Numen is documented in Treveris. ${ }^{30}$ In Gouecourt/Leuci, in the same Belgian province, a dedicator named Padula links the Iunones with the imperial house following the well known formula In h(onorem) $d$ (omus) $d$ (ivinae) (No. 57), very typical in these zones. ${ }^{31}$

\footnotetext{
${ }^{27}$ LANDUCCI 1986, 40-41, with refrences.

${ }^{28}$ PETER 1978, col. 2258; LANDUCCI GATTINONi 1986, 50.

${ }^{29}$ See LIERTZ 1998.

${ }^{30}$ LIERTZ 1998, n. 4.

${ }^{31}$ RAEPSAET-CHARLIER 1975, 1992.
} 


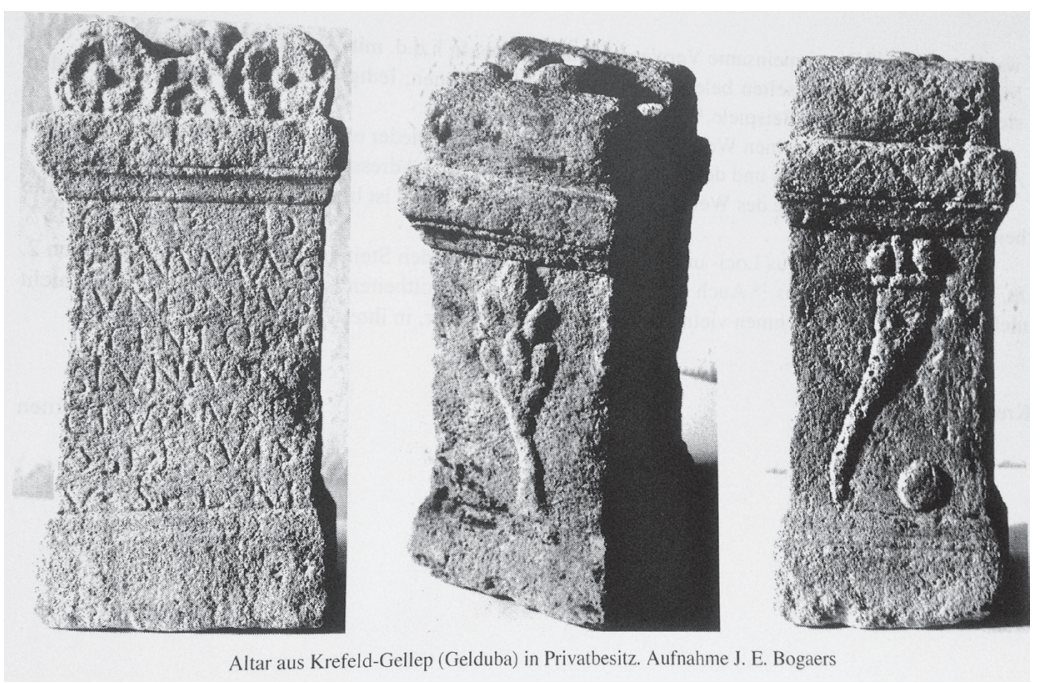

Fig. 3. Altar to the Iunones and the Genius loci from Krefeld-Gellep (photo: J. E. Bogaers)

The Vicani Neriomagenses from Neri-les-Bains/Aquae Neri (in the province of Aquitania) dedicate two altars to the Iunones along with the Numina Augustorum (52), and the epithet Domesticae accompanies the goddesses in an inscription in Zulpich/ Tolbiacum, in Germania Inferior (No. 59). The dedicators are the vicani Tolbiacenses, who seemingly act upon the orders of the deities themselves, which is also the case in another inscription in Wesseling, in the same province (No. 60).

Another particularly interesting adjective is Montanae, found in an inscription dedicated by Cinnmais in Nimes (No. 47). The association with the mountains seems to suggest an interpretatio of local ancestral female deities. Ammianus Marcellinus (16. 10. 3) states that the Mons Matronae (Monginevro) owed its name to a matron who had died there, a clearly wrong explanation. Chilver ${ }^{32}$ already proposed the hypothesis that Mons Matronae was related with the deity who inhabited it, and 9 inscriptions to the Matronae have actually appeared in the Cottian Alps. ${ }^{33}$

The association to the Suleviae documented in an altar in Rinxent/Morini, in the province of Belgium, erected by a L. Cassius Nigrinianus, seems particularly significant (No. 54). The theonym seems unequivocally Celtic, with the same root as the well known Sulis Minerva in Britannia. ${ }^{34}$

Another highly interesting epithet is Gabiae, used for Iunones in two different altars in Germania Inferior. One of them, from Cologne (No. 61), is dedicated by a Masius. The other, from Xanten (No. 62), appears in a monumentum dedicated to Iunonibus sive Gabiabus by an individual called M. Hilarinius Romanius. Also in this city an altar was found dedicated to Iuppiter Optimus Maximus and all the Iunones

\footnotetext{
${ }^{32}$ CHILVER 1941, 188.

${ }^{33}$ LANDUCCI GATTINONI 1986, 79.

${ }^{34}$ CUNLIFFE et al. 1985.
} 
(Iunoni(bus) omnib(us)) by a veteran of Leg. XXX called Iulius Vitalis in his and his family's favour (No. 63).

\section{CULTORES}

Dedicators of the epigraphs where Iunones are mentioned are very varied and of diverse social status. The most remarkable instance is perhaps the inscription of Pratica di Mare/Lavinium (No. 46). It is dated to Tiberius' $38^{\text {th }}$ tribunicia potestas (that is, the year 36) and the dedicator is none other than Spurius Turranius Proculus Gellianus, who is flamen Dialis, flamen Martialis and the holder of a prefecture. Fortunately, this character is known to us through another inscription in Pompeii (CIL X 797=ILS 5004) dating from the Claudius period, whereby we know he did hold military, civilian and religious offices, including flamen Dialis, flamen Martialis, salius praesul, augur, pontifex and also pater patratus populi Laurentis. Should this person, as Landucci proposes, have had a Lavinate background, this inscription, the oldest inscription mentioning the Iunones by a Roman citizen of the equestrian order, ${ }^{35}$ would not only attest to the precocious religious Romanization inherent to Iunones, but would pose highly remarkable questions regarding mutual influences between Italic and Celtic cultures in the development of cults in the south of the Alps. This dedication, striking as it may be, can be added to other dedications made to the Matronae by persons in senatorial and equestrian positions outside Italy. ${ }^{36}$

On other occasions, the threefold name of the dedicator denotes their privileged legal status: this is the case of Sextus Licinius Verecundus (mentioned as dedicator in Aquileia: No. 1), M. Mogetius Hospes (No. 3, Aquileia) or C. Naevius Proculus (from Manerbio: No. 36), L. Caecilius Placidus (from Brescia: No. 18), L. Sart(ius?) Secundus (from Brescia: No. 23), C. Vocianus Surg[ ] (from Brescia: No. 25), L. Valerius Severus and Clodia Corneliana (from Toscolano-Maderno: No. 37), or L. Cassius Nigrinianus (from Rinxent, Belgium: No. 54), as well as the L. Licinius Firmus, documented on the gravestone from Riva di Garda (No. 28) (fig. 4).

However, the names in other inscriptions point to peregrine dedicators (this is the case of Barbara Oldra in Saint-Gilles [ciuitas of Nemausus: No. 48], the Maemilii in Putzdorf [No. 58], Gabianus Masius [Cologne: No. 61]), or even to the world of freedmen. This could be precisely the background of L. Vitruvius Euthetus (Ferrara: No. 34), as well as of T. Flavius Hermes and his wife Metella Ide, from Verona (No. 13). And this is certainly the background of L. Cassius Trophimus, of Valgarata (No. 35), Annia Iuda or L. Clodius Auctus (from Brescia: No. 17 and 19), Aninia (from Carpi, in Emilia: No. 43), a Catia who dedicates an altar to the Iunionibus ancillarum in Radelsdorf, Noricum (No. 68), or Acutia Egloge from Bagnolo Mella (Brixia: No. 31). And possibly freedmen are also Cn. Cornelius Nikanor, from Brescia (No. 20) or

\footnotetext{
${ }^{35}$ LANDUCCI GATTINONI 1986, 26.

${ }^{36}$ LANDUCCI GATTINONI 1986, 61-62.
} 


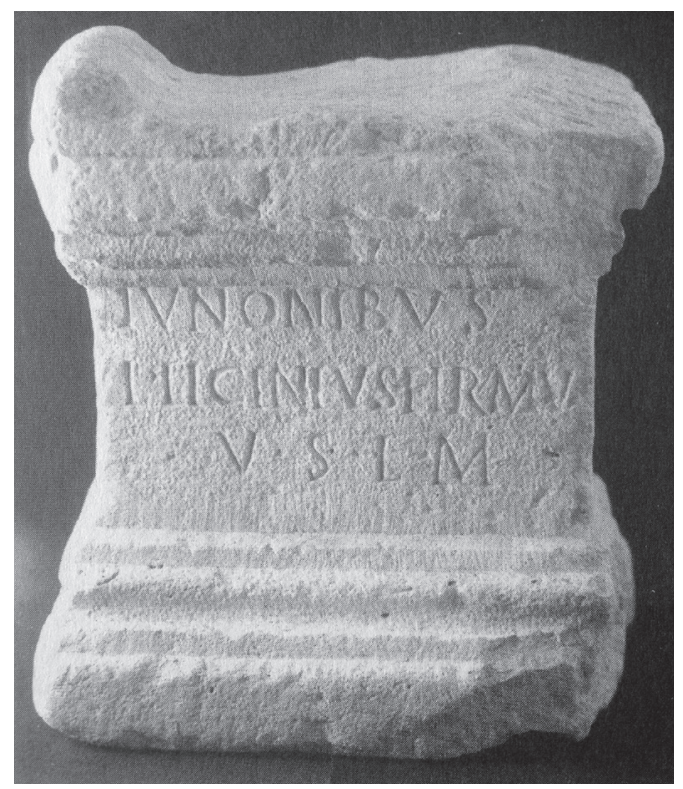

Fig. 4. Inscriptions to the Iunones by Licinius Firmus, Riva di Garda (Trentino) (after BASSI 2008, fig. 3)

L. Tarius Philero, from Parma (No. 44). A Mestrius Faber dedicates an altar in Brescia too (No. 22).

Seviri Augustales appear as dedicators of altars in Verona (No. 12. L. Licinius Hymnus), Como (No. 39, C. Vir[ ] Max[ ], to the Iunones Matronae). Their servus nature is mentioned in inscriptions in Brescia (No. 24, Nicetius, who dedicates an altar to the health of Valeria Iusta).

At times, one inscription may document very different names. This is the case of the inscription in Gouecourt (Belgium: No. 57), where Padula dedicates an altar to the Deae Iunones in favour of S. Sufus Agricola, Regalis, Petturo and Grannica, the latter names being of Celtic origin. The name Brocchilus Brocchi f. of Arsago Serpio, Transpadana (No. 41) also seems clearly Celtic, as well as the name Baro mentioned as the father of already Romanized Valerius who dedicates an altar to the Iunones in Arcisate (Como: No. 40). A similar instance could be that of Rufus Acutius Comincilonis f., from Mezzane (No. 29), whose father had a Celtic name but he already had two Latin nomina.

In short, inscriptions dedicated to Iunones comprise the entire social range, from lavinate Dialis Spurius Turranius Proculus Gellianus (No. 46), to numerous cultores, freedmen of Greek names, including also dedicators whose names are clearly Celtic. 


\section{MONUMENTALIZATION AND ICONOGRAPHY OF THE CULT}

Epigraphy dedicated to Iunones generally documents the fulfilling of a pledge and does not report the construction of monuments in their honour, save for some exceptions. One such exception is the gravestone found in Sankt Georgen/Tarnasicum in Noricum (No. 66), where the cultor had a temple rebuilt, which had become derelict over time, in honour of these deities. Lack of data precludes more detailed information regarding the name of the dedicator.

Another noteworthy instance is an epigraph from Aquileia, where sevir augustalis M. Magius Amaranthus and his wife Magia Vera Ilias had a temple built in a private estate with three statues, a portico, an enclosing wall and a kitchen (No. 2). The name Magius is well documented in Aquileia in the Imperial period amongst families of probable seviral background who enjoy a prosperous economic status, as demonstrated by this epigraph, which could be dated to the second century. ${ }^{37}$ Also in Aquileia another epigraph whose dedicator's name has not been preserved, reports the construction of a portico, a school and perhaps a silver image to Iunones. (No. 4).

The inscription in Carpi (Emilia) dedicated by a freedwoman, Aninia, is quite remarkable. The text (No. 43) explains that the altar is dedicated to the Iunones, along with the place where it stands and the regulations (leges) it contains. According to these, it is legal to carry out repair and refurbishment works, as well as ornamentation and delimitation actions as well as to perform crime-free or fraudulent-free sacrifices. It is not clear in the inscription whether the locus mentioned was simply a piece of land with an altar or a covered temple, though the aforementioned operations seem to point rather to an aedicula.

Triplicity usually defines the iconography of Matres or Matronae, ${ }^{38}$ who are portrayed enthroned, with baskets of flowers or fruit on their laps in Celtic-Germanic backgrounds, as has traditionally been admitted from $\mathrm{Ihm}^{39}$ to Pascal. ${ }^{40}$ This is how they were depicted in the lost altar of Morozzo (Bene Vagienna). ${ }^{41}$ However, in the western Cisalpine, several reliefs depict a higher number of dancing female figures which have been interpreted as figurations of young females devoted to the goddesses. This is the case of the monuments from Angera, Pallanza, Avigliana (fig. 5) and Sommariva Bosco, ${ }^{42}$ with three or five female figures dancing and holding hands amid trees and garlands, denoting woodlands and wilderness. Likewise, the ceramic vase from Capignano Sesia depicts similar female figures, as also seems to be the case in the vase from Biandrate. ${ }^{43}$

The iconography of these Matronae from the Cisalpine region is redolent of the female dancers (Tomba delle danzatrici) on the renowned Peucetian funerary painting

\footnotetext{
${ }^{37}$ LANDUCCI GATTINONI 1986, 34; GIRARDi 2017, 390.

38 BAUCHHENS-NEUMANN 1987; WOOLF 2003; GARMAN 2008.

${ }^{39}$ IHM 1887, 49.

${ }^{40}$ PASCAL 1964, p. 116.

${ }^{41}$ LANDUCCI GATTINONI 1986, 29-30.

42 Spagnolo Garzoli 1996, 102, tav. XXXVI.

${ }^{43}$ http://www.sitbiella.it/novara/libro/pagine/studi_di_sintesi/cultiRomani/page135.html.
} 


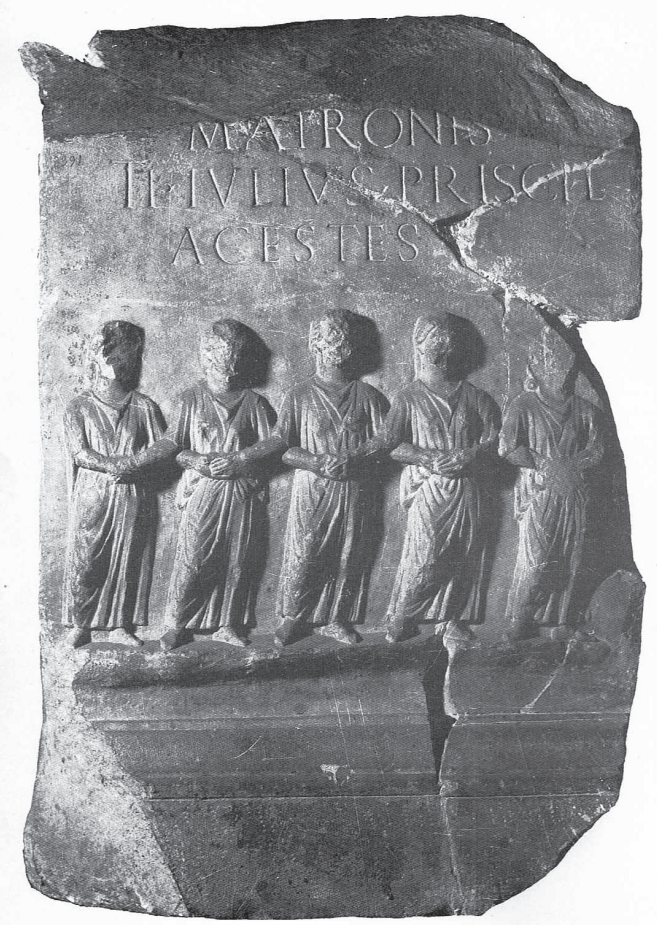

Fig. 5. Ara from Avigliana (photo: Museo Civico di Torino)

of Ruvo di Puglia, dating from the end of the fifth century to the second half of the fourth century $\mathrm{BC},{ }^{44}$ and therefore with a chronology much earlier than the Cisalpine monuments. The altar from Angera, housed at the Museo Civico of Varese, depicts on the left side four female figures ${ }^{45}$ under what appears to be an oak tree with an amphora at its base, which are similar to the three dancers on the back side of the altar of Pallanza, dating from Caligula's period, where the slave Narcissus, who addresses the Matronae to protect the emperor's health, appears on the relief under the epigraph sacrificing an animal, probably a sheep, with an assistant and a flautist on either side. ${ }^{46}$ Finally, in the altar of Avigliana at Museo Civico di Torino, ${ }^{47}$ five female figures representing the Matronae are depicted (fig. 5). The four figures on the left are holding hands, like those in the altar in Pallanza. The one on the right, however, is isolated from the rest, as seems also to be the case of the first of the figures portrayed in the

\footnotetext{
${ }^{44}$ De Julits 2004, 267; PasCale 2009, 297.

${ }^{45}$ SENA Chiesa 1982, 116-124; LandUCCI GatTinOni 1986, fig. 1.

${ }^{46}$ MANini CALDERINI 1972, figs. 1-2; LANDUCCI GATTINONi 1986, appendix no 75, fig. 3.

${ }^{47}$ GUZO-MosCaT-SUSini 1995, 177, 263 n. 757; LANDUCCI GATTINONI 1986, fig. 2.
} 
altar of Angera, who presides over the parade moving towards the right and which could be dated to somewhere between the years 41 and 6, according to Brusin. ${ }^{48}$

Landucci Gattinoni ${ }^{49}$ believes that the female figures of the altars in Pallanza, Angera and Avigliana could represent the goddesses themselves, not as austere Mothers but as nature's Nymphs. These reliefs would develop a new type of iconography of the goddesses differing from northern models of the Matres or Matonae with similarities to figures in central-southern Italy. ${ }^{50}$ It could be assumed a similar figuration for our Iunones, at least in the case of those from the Cisalpine region, but an iconography of this kind has not appeared associated to these goddesses.

\section{CONCLUSIONS}

According to the hypothesis put forward by Landucci Gattinoni, ${ }^{51}$ the fact that in Regio X only 7 altars to the Matronae have been documented, while 29 monuments have been attested to the Iunones, might suggest that the cult to these goddesses could have been introduced by Italic people who, from the second century BC onwards, settled in the eastern part of northern Italy. It might not be casual that the oldest inscription to the Iunones comes from Lavinium (No. 46), and moreover, in Tor Tignosa, in the environs of Lavinium, three ancient cippi from the late fourth or early third century BC were found with the dedications Neuna Fata, Neuna dono and Parca Maurtia dono. ${ }^{52}$ The number of Fata or Parcae (Gell. 3. 16. 9-11, quoting Varro), goddesses of human fate, could amount to three possibly through the influence of the three Greek Moirai, and we know that ancient statues of the tria Fata existed in the Roman Forum (Plin. NH 29. 19). In the Cisalpine several inscriptions to the Fatae and to the Parcae are attested to, ${ }^{53}$ and their assimilation to Celtic Matronae could illustrate a similar interpretatio of traditional female through the Iunones.

The cult to Iunones, as is known through epigraphs in the Cisalpine, contributes therefore a testimony of the existence of a genuine and vigorous indigenous tradition and of a permanent process of acculturation between Celtic populations dominated by Rome and the Italic and Latin populations settled in northern Italy. But contrary to what Pascal ${ }^{54}$ or Landucci Gattinoni ${ }^{55}$ claim, epigraphy does not validate the substantial identity of the Matronae and Iunones in the Cisalpine. Only 4 of the total 97 entries on Matronae and Iunones (those from Macerata Feltria [No. 45], Verona [No. 10], Como [No. 39] and Arcisate [No. 40]) are jointly dedicated to both plural designations, and that in my opinion makes the tout court identification of both theonyms

\footnotetext{
${ }^{48}$ LANDUCCI GATTINONI 1986, 32.

${ }^{49}$ LANDUCCI GATTINONI 1986, 32.

${ }^{50}$ SENA CHIESA 116-117, 124.

${ }^{51}$ LANDUCCI GATTINONi 1986, 75.

52 Degrassi 1972, Nos. 10-12.

53 See ZACCARIA 2001-2002, 151.

${ }^{54}$ PASCAL 1964, 187.

${ }^{55}$ LANDUCCI GATTINONi 1986, 19.
} 
rather problematic. Moreover, as previously stated, Matronae are clearly predominant in the west, in Regio XI, whereas Iunones are more prevalent in Regio X (save for the territory of Brescia, bordering Regio XI).

The Iunones, as the Dianae testamented only in three inscriptions found in Romano-Celtic areas, ${ }^{56}$ seem to be the result of an interpretatio process between local goddesses and the Roman Juno. This process could be facilitated by several elemenents. On one hand, Dumézil's proposal ${ }^{57}$ arguing that Iuno was a goddess of Indo-European origin, a proper tripartite deity embodying warlike power, fecundity and sacred royalty (a threefold function that might have been perpetuated until much later, as the busts of the "Three holy women" of the Landesmuseum Württemberg in Stuttgart seem to imply: see fig. 1 on p. 216), should not be dismissed. On the other, Ihm's hypothesis ${ }^{58}$ that Roman Juno's protecting role could have been transferred onto social communities seems validated by inscriptions such as those from Bergamo $(C I L \mathrm{~V}$ : Iunoni Pagi Fortunensis) or Treveris (CIL XIII 3642) dedicated to the Iunones and the Genius. The distinctive plurality of the female protective deities in Celto-Germanic environments would have no doubt favoured the plurality of the Roman Juno as well, given the paucity of epigraphical testimonies of the Roman Juno in the Cisalpine area, while on the contrary the Iunones, Matronae or Matres are totally ignored in ancient literary sources. Juno, due to her great prestige and popularity as a member of the Capitoline triad, is pluralized as (another) form to make visible ancestral goddesses. Later on, from the Cisalpine areas - and specially the Regio X - where most of the dedications to the Iunones appear, their cultores, belonging to the entire social range, would expand their cult - associated or not to other deities - specially to provinces such as Germania Inferior, and to a lesser extent to Gallia and Noricum, with only very few manifestations in the rest of Italy, in a typical process of the migrations and globalization inherent to the Roman Empire.

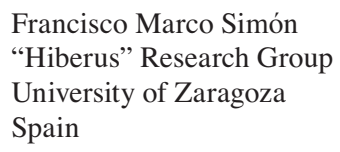

\section{BIBLIOGRAPHY}

BASSI, C. 2008: Una dedica alle Iunones da Riva del Garda (Trentino). In Sartori, A. (a cura di): Dedicanti e cultores nelle religioni celtiche. VIII Workshop F.E.R.C.A.N., Gargnano del Garda (9-12 maggio 2007). Milano, pp. 43-59.

BauchHens, G. - Neumann, G. (Hrsg.) 1987: Matronen und verwandte Gottheiten. Bonn

\footnotetext{
${ }^{56}$ Cf. n. 2.

${ }^{57}$ DUMÉZIL 1954, 105-119; 1974, 303-310.

${ }^{58}$ IHM's hypothesis 1894.
} 
BAYET, J. 1957: Histoire politique et psychologique de la religion romaine. Paris Cunliffe, B. et alii 1985: The Temple of Sulis Minerva at Bath. 3 vols. Oxford

ChiAi, G. F. - HäUssler, R. - Kunst, K. (Hrsg.) 2012: Interpretatio Romana/ Graeca/Indigena. Religiöse Kommunikation zwischen Globalisierung und Partikularisierung [Mediterraneo Antico. Economia, Società, Culture XV 1-2]. Pisa-Roma

ChILver, G. E. F. 1941: Cisalpine Gaul. Social and Economic History from 49 BC to the Death of Traian. Oxford

DEGRASSI, A. 1972: Inscriptiones Latinae Liberae Rei Publicae. Firenze

DuMÉZIL, G. 1954: Juno S.M.R. Eranos 52, pp. 105-119.

DUMÉZIL, G. 1974: Religion romaine antique. Paris

GARMAN, A. G. 2008: The Cult of the Matronae in the Roman Rhineland: An Historical Evaluation of the Archaeological Evidence. Lewiston, NY

GIRARDI, C. 2017: Sulle tracce dei luoghi di culto delle divintà plurali in Gallia Cisalpina. In Häussler, R. - King, A. (eds): Celtic Religions in the Roman Period. Personal, Local and Global. Aberystwyth, pp. 387-400.

Gómez PantojA, J. 1999: Las Madres de Clunia. In Villar, F. - Beltrán, F. (eds): Pueblos, lenuas y escrituras en la Hispania Prerromana. Actas del Vii Coloquio sobre Lenguas y Culturas Paleohispánicas (Zaragoza, 12 a 15 de Marzo de 1997). Salamanca-Zaragoza, pp. 421-432.

GREGORI, G. L. 2000: Brescia romana. Ricerche di prosopografia e storia sociali. II. Analisi ei documenti. Roma

Guzzo, P. G. - Moscati, S. - Susini, G. (eds) 1995: Antichi genti d'Italia. Roma

HeICHELHEIM, F. 1930: Matres. In Realencyclopädie der klassischen Altertumswissenschaft 14, pp. 2213-2250.

http://commons.wikimedia.org/wiki/File:Micheldorf_Lorenzenberg_68_Filialkirche_ hl_Laurentius_Westwand_Iunones-Weihealtar-Fragment_07082014_056.jpg (consulted on 17 January 2018)

IHM, M. 1887: Der Mutter- oder Matronenkultus und seine Denkmäler. Bonner Jahrbücher 83, pp. 1-200.

IHM, M. 1894: Iuno; Matres. In Roscher, W. H.: Ausführliches Lexicon der griechischen und römischen Mythologie. Leipzig, Vol. II, coll. 615-618; coll. 2464-2488.

JufER, N. - LugINBÜHL, T. 2001: Répertoire des dieux galois. Les noms des divinités celtiques connus par l'épigraphie, les textes anticues et la toponymie. Paris

JuliIs, E. M. DE 2004: The Etruscans in Puglia. In Bernardini, P. - Camporeale, G. (eds): The Etruscans outside Etruria. Los Angeles, pp. 260-267.

LAMBRECHTS, P. 1942: Contribution à l'études des divinités celtiques. Brugge

LANDUCCI GATTINONI, F. 1986: Un culto celtico nella Gallia Cisalpina. Le MatronaeIunones a sud delle Alpi. Milano

LIERTZ, U.-M. 1998: Kult und Kaiser. Roma

MANini CAlderini, O. 1972: I Celti e le "Dee Matronae" nel Novarese en el Bieliese. Boll. Novara 63, pp. 47-65.

PASCAL, C. B. 1964: The Cults of the Cisalpine Gaul. Bruxelles 
PASCAL, R. 1941: On the Origins of the Liturgical Drama of the Middle Ages. The Modern Language Review 36.3, pp. 369-387.

PASCALE, E. 2009: Death and Resurrection in Art. Los Angeles

PETER, R. 1978: Hercules. In Roscher, W. H.: Ausführliches Lexikon der griechischen und römischen Mythologie. Hildesheim-New York, colls. 2253-2298. (Nachdruck der Ausgabe Leipzig 1884-1886)

RAEPSAET-CHARliER, M.-TH. 1975: La datation des inscriptions latins dans les provinces occidentales de l'Empire Romain d'après les formules "In h(onorem) d(omus) d(ivinae)" et “DEO, DEAE". In Aufstieg und Niedergang der römischen Welt II 3, pp. 232-282.

RAePSAet-CHARlier, M.-TH. 1993: Diis deabusque sacrum. Formulare votif et datation dans les Trois-Gaules et les Deux Germanies. Paris

RIVES, J. 1992: The Iuno Feminae in Roman Society. Echos du monde classiquel Classical Views 36 (N.S. 11), pp. 33-49.

Rose, H. 1948: Ancient Roman Religion. London

SARTORI, A. 1995: Un viandante tra "Iuno e le Iunones". Epigraphica 57, pp. 235-237.

Schilling, R. 1979: Rites, cultes, dieux de Rome. Paris

SenA ChIESA, G. 1982: Candida Marmorum Fragmenta. Spunti di ricerca su alcuni rilievi romani di Angera. In Studi in onore di Mario Bartalone. Varese, pp. $11-125$.

SPAGNOLO GARZOLI, G. 1996: Un aspetto dell'iconografia del culto delle Matrone su ceramica commune a rilievo. Quaderni della Soprintendenza archeologica del Piemonte 14, pp. 89-115.

Whatmough, J. 1937: The Foundations of Roman Italy. London

WissowA, G. 1912: Religion und Kultus der Römer. Zweite Auflage. München

Woolf, G. D. 2003: Local Cult in Imperial Context: the Matronae revisited. In Noelke, P. - Naumann-Steckner, F. - Schneider, B. (Hrsg.): Romanisation und Resistenz in Plastik, Architektur und Inschriften der Provinzen des Imperium Romanum. Neue Funde und Forschungen. Mainz, pp. 131-138.

ZACCARIA, C. 2001-2002: Alla ricerca di divinità "celtiche" nell'Italia settentrionale in età romana. Revisione della documentazione per le Regiones IX, X, XI. Veleia 18-19, pp. 129-166. Annexe: Votive Altars to the Iunones

ANNEXE: VOTIVE ALTARS TO THE IUNONES

\section{VENETIA ET HISTRIA / REGIO X}

1. Aquileia (CIL V 00780=InscrAqu-01, 00235; EDCS-01600057): Iunonibus / sacrum / Sex(tus) Licinius / Verecundus

2. Aquileia (CIL V 00781=InscrAqu-01, 00236=D 03119=IEAquil 00221=RSH 00056; EDCS-01600058): Iunonibus sacrum / M(arcus) Magius M(arci) l(ibertus) Amaranthus / IIIIIIvir et / Magia M(arci) f(ilia) Vera Magia M(arci) l(iberta) Ilias / aedem signa III portic(um) cum marceri(i)s et / culina et locum(!) in quo ea sunt / votum solverunt / loco privato. 
3. Aquileia (CIL V 00782 (p. 1024)=InscrAqu-01, 00237; EDCS-01600059): Iunonibus / sacrum / M(arcus) Mogetius / Hospes v(otum) s(olvit).

4. Aquileia (CIL V 00842=InscrAqu-01, 00238; EDCS-01600120): Jlunia portic[um(?) 3] / [3]dia scholam [3] / [3] simo ex argento [3] / [3]P[3] / [3 Iu]noni[bus(?) 3] / v(otum) s(olvit) [

5. Aquileia (InscrAqu-01, 00240; EDCS-01300108): Iun(onibus?) s(acrum)

6. Aquileia (CIL V 08230=InscrAqu-01, 00239=IEAquil 00221; EDCS-59200189): Iunonibu $[s$

7. Verona (CIL V $03234=$ Maffeiano 00020; EDCS-04202282): [I]unoni[b(us)] / $\operatorname{sacr}($ um)

8. Verona (CIL V 03235; EDCS-04202283): Iunonib(us) / sacrum / Ameryllus.

9. Verona (CIL V 03236; EDCS-04202284): Iunonibus / M(arcus) Caesius / M(arci) f(ilius) C(aius) Caesius / fratres / v(otum) s(olvit) l(ibens) m(erito).

10. Verona (CIL V 03237; EDCS-04202285) Iunonib(us) A[ug(ustis?)] / Matron[is 3]

11. Verona (CIL V 03238; EDCS-04202286): Iunonib(us) / Aug(ustis) / sacrum.

12. Verona (CIL V 03239=D 03116=RSH 00191; EDCS-04202287): Iunonibus / Aug(ustis) / L(ucius) Licinius Hymnus / VIvir / v(otum) s(olvit) l(ibens) m(erito)

13. Verona (CIL V 03240=D 03117=Maffeiano 00021; EDCS-04202288): Iunonibus / Aug(ustis) sac(rum) / Metella Ide nomine / suo et / T(iti) Flavi Hermetis / viri sui d(onum) d(edit).

14. Verona (AE 1946, 00134; EDCS-15300602): Exspectata / Domnabus(!) / Iunonibus / v(otum) s(olvit) l(ibens) m(erito).

15. Verona (AE 1946, 00133; EDCS-15300601): [I]unonibu[s] / C(aius) Vibius / [3] ippu[s]

16. Verona (Pais 00625; EDCS-08000399): Iunonibus / sacrum / v(otum) s(olvit) l(ibens) m(erito).

17. Brescia/Brixia (CIL V 04221=InscrIt-10-05, 00028; EDCS-04203276): Iunonibus / Annia L(uci) l(iberta) Iuda / pro suis / v(otum) s(olvit).

18. Brescia/Brixia (CIL V 04222=InscrIt-10-05, 00029; EDCS-04203277): Iuno/ nibus / v(otum) s(olvit) l(ibens) m(erito) L(ucius) Caecil(ius) / Placidu/s.

19. Brescia/Brixia (CIL V 04223=InscrIt-10-05, 00030=D 03115; EDCS04203278): Iunonibus / L(ucius) Clodius / Arbusculae l(ibertus) / Auctus / v(otum) s(olvit) l(ibens) m(erito).

20. Brescia/Brixia (CIL V 04224=InscrIt-10-05, 00031; EDCS-04203279): Cn(aeus) Cornel(ius) / Nikanor / Iunonibus / v(otum) s(olvit) l(ibens) m(erito).

21. Brescia/Brixia (CIL V 04224a=InscrIt-10-05, 00032; EDCS-04203280): Iuno(nibus) / Iusta / v(otum) s(olvit) l(ibens) m(erito).

22. Brescia/Brixia (CIL V 04225=InscrIt-10-05, 00033; EDCS-04203281): Iunonibus / v(otum) s(olvit) l(ibens) m(erito) / Mestrius / faber.

23. Brescia/Brixia (CIL V 04226=InscrIt-10-05, 00034; EDCS-04203282): Iunonib(us) / L(ucius) Sart(ius?) / Secundus.

24. Brescia/Brixia (CIL V 04227=CIL V *01105,03=InscrIt-10-05, 00035; EDCS04203283): Iunonibus / pro sal(ute) / Val(eriae) Iustae / Nicetius / serv(us) v(otum) s(olvit). 
25. Brescia/Brixia (CIL V 04228=InscrIt-10-05, 00810; EDCS-04203284): Iunonibus / v(otum) s(olvit) l(ibens) m(erito) / C(aius) Vocianu(s) Surg() / sacrum.

26. Brescia/Brixia (InscrIt-10-05, 00027=AE 1912, 00248; EDCS-04700007: VEDI(?) / Iunonib(us).

27. Brescia/Brixia (SupIt-25-B, 00082=AE 2010, 00581; EDCS-48700143): Iunonib(us) / [.

28. Riva del Garda/Brixia (SupIt-25-B, $00103=A E$ 2008, 00588; EDCS-48700156): Iunonibus / L(ucius) Licinius Firmu(s) / v(otum) s(olvit) l(ibens) m(erito).

29. Mezzane/Brixia (InscrIt-10-05, 00837=AE 1975, 00434; EDCS-04700245): Rufus Acutius / Comincilonis [f(ilius)?] / Iunonibu[s] / iussus fecit l(ibens) m(erito) [s(olvit)?]

30. Calvisano/Brixia (InscrIt-10-05, 00838=AE 1975, 00432; EDCS-04700246): Iunonibus / Aug(ustis) / Euelpistus / M(arci) I() F() v(otum) s(olvit) l(ibens) m(erito).

31. Bagnolo Mella/Brixia (InscrIt-10-05, 00863=AE 1952, 00132; EDCS04700254): Iunonibus / Acutia C(ai) l(iberta) / [Eg]loge v(otum) s(olvit) l(ibens) m(erito).

32. Carzago Riviera/Brixia (InscrIt-10-05, 01279; EDCS-04700382): [Iu]nonib[us] / [

33. Lazise (SupIt-11-A, $00004=A E$ 1993, 00778; EDCS-10800096): Iunonib(us) / M(arcus) Minici(us) / Minicia/nus / v(otum) s(olvit) l(ibens) m(erito).

34. Ferrara (CIL V 02380; EDCS-04201433): Iunonibus / sacr(um) / L(ucius) Vitruius / Euthetus / v(otum) s(olvit) l(ibens) m(erito).

35. Valgatara/Arusnates (CIL V 03901 (p. 1077); EDCS-04202953): L(ucius) Cassius / Fulvi lib(ertus) / Trophimus / Iunonibus / v(otum) s(olvit).

36. Manerbio (CIL V 04157=InscrIt-10-05, 00914; EDCS-04203211): Iunonib(us) / C(aius) Naevius / Proculus / v(otum) s(olvit) l(ibens) m(erito).

37. Toscolano-Maderno (CIL V 04854 (p 1080)=CIL V*00429,241=InscrIt-10-05, 01016=Maffeiano 00056; EDCS-05100003): D(is) S(anctis) / Herculi et // Iunonibus // L(ucius) Valerius Selverus et Clodi/a Corneliana / pro L(ucio) Valerio / Corneliano / v(otum) s(olverunt) l(ibentes) m(erito).

\section{TRANSPADANA / REGIO XI}

38. Como/Comum (CIL V 05248 =IRComo-Su, 00006 =NSA-1917-272=AE 1917/18, 00123 =AE 1922, +00035; EDCS-05100401): Iunonibus / L(ucius) Minicius / Severus / VIvir et Aug(ustalis) / ex voto.

39. Como/Comum (CIL V 05249=IRComo-Si, 00001=D 03122; EDCS-05100402): Iunonib(us) / Matron(is) / ex visu / C(aius) Vir() Max() // Iun(onibus) / C(aius) $V() M()$.

40. Arcisate (CIL V 05450=D 04826; EDCS-05100604). Matronis / Iunonibus / Valerius / Baronis f(ilius) / v(otum) s(olvit) l(ibens) m(erito)

41. Arsago Seprio/Sibrium (CIL V 05535=ArsagoSeprio 00012; EDCS-05100688): Iunoni/bus Bro/cchilo / Brocc/hif(ilius) v(otum) s(olvit) l(ibens) m(erito). 
42. Liscate (Epigraphica-1995-236=AE 1995, 00643):

Iunonib(us) / sacrum / L(ucius?) Avianius / et(?) Peli[3].

\section{AEMILIA / REGIO VIII}

43. Carpi (CIL XI 00944=D 04909=Epigraphica-1984-219=AE 1983, 00417; EDCS-20402387) Aninia Sex(ti) l(iberta) Ge(niis?) Iunonibus hanc / aram locumque iis legibus dedicavit / si quis sarcire reficere ornar(e) coronar(e) volet licet / et si quit sacrifici quo volet ferre et ibi ubi volet uti sine / scelere sine fraude lic [et]

44. Parma (CIL XI 01048; EDCS-20402492): Iunonibus / L(ucius) [T]arius / Philero / s(olvit) l(ibens) m(erito).

\section{VMBRIA / REGIO VI}

45. Pitinum Pisaurense (CIL XI 08082; EDCS-21300654): Matronis / Iunonibus / [6] / sacrum / [

\section{LATIVM ET CAMPANIA / REGIO I}

46. Pratica di Mare/Lavinium (CIL XIV 04176; EDCS-05802145): [Honori Ti(beri)] C[a]e[saris divi] / [3] Augus[ti] f(ilii) [3] / [Augusti pontif]icis maximi / [trib(unicia) pot(estate)] XXXVIII / [Sp(urius) Turranius L(uci) f(ilius)] Fab(ia) Proculus / [Gellianus fla]men Dialis / [flamen Marti]alis praefect(us) / [3 ex vo]to(?) Iunonibus / [d(onum)] d(edit)

\section{GALLIA NARBONENSIS}

47. Nîmes/Nemausus (CIL XII 03067=D 03121=INimes 00001; EDCS-09201534): Iunonib(us) / Montan(is) / Cinnamis / v(otum) s(olvit)

48. Saint-Gilles/Nemausus (CIL XII 04101=CIL XII *00120 (p 34*)=CAG-13-05, 00812=CAG-30-02, p. 115=AE 2004, +00875; EDCS-09202580): Iunonibus / Aug(ustis) / V[3]olt() Barbara / Oldra v(otum) s(olvit) l(ibens) m(erito)

49. Saint-Remy-de-Provence/Glanum (CAG-13-02, p. $342=A E$ 1958, 00305; EDCS13500316): P]eregri[na] / Iunonibus / v(otum) s(olvit) l(ibens) m(erito).

\section{AQVITANIA}

50. Bordeaux/Burdigala (CIL XIII 00567=ILA-Bordeaux 00024; EDCS-10400737): Iunonibus / Iuliae et Sextiliae / [.

51. Agen/Nitiobroges/Aginnum (CIL XIII 00914=ILA-Niti 00001=D $03118=C A G-$ 47, p 132=AE 1891, 00112=AE 1892, 00066; EDCS-10401086): Iunonibus / Augustalib(us) / porticum et / maceriam / Capito Luci f(ilius) / et Iulia ux\{s\}or / v(otum) s(olverunt) l(ibentes) m(erito). 
52. Neris-les-Bains/Aquae Neri (CIL XIII 01373; EDCS-10500263): N(umini)b(u)s A(u)g(ustoru)m // I(unoni)b(u)s v(ica)ni N(erioma)g(iense)s(?)

53. Neris-les-Bains/Aquae Neri (CIL XIII 01374=CAG-03, p 180; EDCS-10500264): Numinibus / Augustorum / et Iunonibus / vicani / Neriomagienses

\section{BELGICA}

54. Rinxent/Morini (CIL XIII 03561=D 04775=CAG-62-02, p 427; EDCS10600329): Sulevis Iuno/nibus sacr(um) / L(ucius) Cas(sius) Nigri/n[ianus(?) pro] / se [3]

55. Trier/Augusta Treverorum (CIL XIII 03642; EDCS-10600410): Genio e[t 3] / Iunonibu[s

56. Trier/Augusta Treverorum (Nesselhauf 00008=CSIR-D-04-03, 00099=AE 1931, 00070; EDCS-11202088): Numinibus / Aug(ustorum) et Iunonib(us) / L(ucius) Martius / Gasculus v(otum) s(olvit) l(ibens) m(erito)

57. Gouecourt/Leuci (CIL XIII 04704=CAG-88, p 229; EDCS-10601668 In h(onorem) d(omus) d(ivinae) / deabus Iu/nonibus Pa/dula pro sa/lute S(exti) Rufi / Agricol(a)e et / Regalis et / Petturonis / et Grannicae / v(otum) s(olvit) l(ibens) m(erito)

\section{GERMANIA INFERIOR}

58. Putzdorf (CIL XIII 07860; EDCS-11100084): Iunonibus / Maemilius / Genialis / pro se et Maemiliis / Avito et Lupula(e) / liberis suis.

59. Zulpich/Tolbiacum (CIL XIII 07920=Lehner 00545=Matronen p. 108; EDCS11100145): Iunoni/bus Dom(esticis) / NI[3] / vican[i T]/olbia[ce]n(ses) / ex [imp(erio) ips(arum?)]

60. Wesseling (CIL XIII 08158=Lehner 00546; EDCS-11100376): [I]unonibus / C(aius) Domiti/us Quietus / imp(erio) ip(sarum) l(ibens).

61. Köln/Colonia Claudia Ara Agrippinensium (CIL XIII 08192=RSK00045=IKöln 00068; EDCS-01200030): Iunoni/\{i\}bus Ga/biabus / Masius / votum retulit

62. Xanten/Colonia Ulpia Traiana (CIL XIII 08612=AE 1905, 0024; EDCS11100706): Iunonibus / sive Gab/iabus m(onumentum) / M(arcus) Hilarinius / Romanius / v(otum) s(olvit) l(ibens) m(erito)

63. Xanten/Colonia Ulpia Traiana (CIL XIII 08622=Legio-XXX, 00122=AE 1905, 00230; EDCS-11100716): I(ovi) O(ptimo) M(aximo) / et Iunonib(us) / omnib(us) Iul(ius) / Vitalis vet(eranus) / leg(ionis) XXX pro / se et suis ex\{s\} / [iu]sso

64. Köln/Colonia Claudia Ara Agrippinensium (IKöln 00067=AE 1990, 00731; EDCS-01100063): Iunonibus / pro / Domitia / Avita / patres / v(otum) s(olverunt) l(ibentes) m(erito)

65. Krefeld/Gelduba (ZPE-141-298=AE 2002, 01038; EDCS-28900027): In ho(norem) // d(omus) d(ivinae) / et num(ini) Aug(usti) / Iunon(i)bus / et Gen(io) loci / Silvinius No/cturnus p[r]/o se et suis / v(otum) s(olvit) l(ibens) m(erito) 


\section{NORICVM}

66. Sankt Georgen/Tarnasicum (CIL III 04766=ILLPRON 00427=AEA 2005, +00007; EDCS-14500055): [3 I]unonibus / [templum] vetustate / [conlapsum] restituit A[3] / [3]nus Castruc(i) / [3] l(ibens) v(otum) s(olvit)

67. Micheldorf/Noreia (CIL III 05030=CIL III 11621=ILLPRON 00309=AEA 2008, +00029; EDCS-14500336): Gracc() Civ[3] / Iunonibu[s] / [

68. Radelsdorf (ILLPRON $00383=$ Leber 00167=Gerstl 00059; EDCS-14400145): Catia / Quarti / lib(erta) Iunoni/bus ancilla/rum v(otum) s(olvit) l(ibens) m(erito). 
